\title{
Oxidation of Tyrosine-Phosphopeptides by Titanium Dioxide Photocatalysis
}

\section{Ruokolainen, Miina}

2016-06-22

Ruokolainen, M , Ollikainen , E , Sikanen , T , Kotiaho , T \& Kostiainen , R 2016 , ' Oxidation of Tyrosine-Phosphopeptides by Titanium Dioxide Photocatalysis ' , Journal of the American Chemical Society , vol. 138 , no. 24 , pp. 7452-7455 . https://doi.org/10.1021/jacs.6b02472

http://hdl.handle.net/10138/224450

https://doi.org/10.1021/jacs.6b02472

other

publishedVersion

Downloaded from Helda, University of Helsinki institutional repository.

This is an electronic reprint of the original article.

This reprint may differ from the original in pagination and typographic detail.

Please cite the original version. 


\title{
Oxidation of Tyrosine-Phosphopeptides by Titanium Dioxide Photocatalysis
}

\author{
Miina Ruokolainen, ${ }^{\dagger}$ Elisa Ollikainen, ${ }^{\dagger}$ Tiina Sikanen, ${ }^{\dagger}$ Tapio Kotiaho, $^{\dagger, \dagger}$ and Risto Kostiainen ${ }^{*}{ }^{\dagger}$ \\ ${ }^{\dagger}$ Division of Pharmaceutical Chemistry and Technology, Faculty of Pharmacy, University of Helsinki, P.O. Box 56, Viikinkaari 5E, \\ FI-00014 Helsinki, Finland \\ ${ }^{\ddagger}$ Department of Chemistry, University of Helsinki, P.O. BOX 55, A.I. Virtasen aukio 1, FI-00014 Helsinki, Finland
}

Supporting Information

ABSTRACT: Protein phosphorylation has a key role in cell regulation. Oxidation of proteins, in turn, is related to many diseases and to aging, but the effects of phosphorylation on the oxidation of proteins and peptides have been rarely studied. The aim of this study was to examine the mechanistic effect of phosphorylation on peptide oxidation induced by titanium dioxide photocatalysis. The effect of phosphorylation was compared between nonphosphorylated and tyrosine phosphorylated peptides using electrospray tandem mass spectrometry. We observed that tyrosine was the most preferentially oxidized amino acid, but the oxidation reaction was significantly inhibited by its phosphorylation. The study also shows that titanium dioxide photocatalysis provides a fast and easy method to study oxidation reactions of biomolecules, such as peptides.

$\mathrm{R}$ eversible phosphorylation of tyrosine, threonine, and serine is among the most important mechanisms in cell-signaling. ${ }^{1}$ Tyrosine kinases and protein tyrosine phosphatases catalyze the specific phosphorylation and dephosphorylation of tyrosine, respectively. ${ }^{2,3}$ Phosphorylation of tyrosine residues is involved in the regulation of various cellular processes, such as proliferation, differentiation, cell cycle progression, cell adhesion, and metabolic homeostasis. Owing to the association of these processes with cancer, tyrosine kinases and protein tyrosine phosphatases are studied as cancer drug targets, and several tyrosine kinase inhibitors are in clinical use for anticancer treatment. ${ }^{4}$

On the other hand, oxidative stress and protein oxidation are implicated in several diseases, ${ }^{5}$ and tyrosine is one of the amino acids that are most susceptible to oxidation. ${ }^{6,7}$ Although the oxidation of peptides is relatively well-known, the effects of phosphorylation on oxidative stress have been rarely studied. In an electrochemical oxidation study, ${ }^{8}$ phosphorylation at the tyrosine residue was shown to prevent its oxidation, giving reason to believe that phosphorylation may play a role in protein oxidation in vivo. However, the study was performed using electrochemical oxidation that begins with single electron transfer, which is not necessarily the most biologically relevant oxidation mechanism.

Titanium dioxide $\left(\mathrm{TiO}_{2}\right)$ photocatalysis is an oxidation method that has found wide use in self-cleaning materials and water purification, where the general aim is to completely mineralize and detoxify the organic pollutants. ${ }^{9}$ Inspired by the capability of $\mathrm{TiO}_{2}$ photocatalysis to oxidize organic compounds, its feasibility for simulation of phase I metabolism of drugs has also been studied recently. ${ }^{10-13} \mathrm{TiO}_{2}$ photocatalysis can generate the same reactive oxygen species as in biological systems, namely hydroxyl radicals $\left({ }^{\circ} \mathrm{OH}\right)$ and superoxide anions $\left(\mathrm{O}_{2}{ }^{\bullet-}\right){ }^{9} \mathrm{UV}$ light with higher energy than that of the band gap of $\mathrm{TiO}_{2}$ excites electrons to the conduction band under $\mathrm{TiO}_{2}$ photocatalysis, which leaves holes on the valence band. The electrons on the conduction band can reduce molecular oxygen to superoxide. Reactions of valence band holes with water produce hydroxyl radicals. A hole can also accept an electron directly from an organic molecule adsorbed onto the $\mathrm{TiO}_{2}$ surface.

$\mathrm{TiO}_{2}$ photocatalysis has been proposed as an alternative protein and peptide digestion method ${ }^{14}$ and used to study the byproducts of toxic microcystin peptides produced by cyanobacteria, ${ }^{15,16}$ but to our knowledge, it has not been used to study the site of oxidation of proteins or peptides per se. As phosphorylation of the tyrosine residue has a key role in the cellular processes, its effect on the oxidation process was addressed in this study. $\mathrm{A} \mathrm{TiO}_{2}$ photocatalytic oxidation method was developed to compare the effect of phosphorylation with the help of five peptides that have the same sequence and three tyrosine residues of which none (TRDIYETDYYRK, IR0), all (TRDIpYETDpYpYRK, IR3), or one of the three were phosphorylated (TRDIpYETDYYRK, IR1A; TRDIYETDpYYRK, IR1B; TRDIYETDYpYRK, IR1C) (Supporting Information, Table S1).

The photocatalytic reaction mixture $(100 \mu \mathrm{L})$ contained 100 $\mu \mathrm{M}$ peptide, $0.1 \mathrm{~g} \mathrm{~L}^{-1} \mathrm{TiO}_{2}$ Degussa P25 particles and $0.01 \%$ ammonium hydroxide. Photocatalytic reactions were performed in duplicate and compared with blanks prepared without the peptide. The samples were magnetically stirred while exposed to UV for 2, 4, 6, 8, 10, and $15 \mathrm{~min}$ from above (without cover) using a 5000-PC Series Dymax UV Curing Flood Lamp (Dymax Light Curing Systems, Torrington, CT, USA; nominal intensity $225 \mathrm{~mW} \mathrm{~cm}^{-2}$ ). After UV exposure, the $\mathrm{TiO}_{2}$ particles were removed by centrifugation at $13,200 \mathrm{rpm}$ for $10 \mathrm{~min}$. The supernatant $(90 \mu \mathrm{L})$ was then subjected to another centrifugation at $13,200 \mathrm{rpm}$ for $10 \mathrm{~min}$, and $8 \mu \mathrm{L}$ of methanol was added to the second supernatant $(72 \mu \mathrm{L})$ prior to analysis. The samples were analyzed using an ultrahigh-performance liquid chromato-

Received: March 7, 2016

Published: June 6, 2016 
Table 1. Proposed Diagnostic Product Ions of the Reaction Products ${ }^{a}$

\begin{tabular}{|c|c|c|c|c|c|c|c|c|c|c|c|}
\hline $\begin{array}{l}\text { peptide/ } \\
\text { product }\end{array}$ & $\begin{array}{l}\text { oxidation } \\
\text { site }\end{array}$ & $\begin{array}{c}t_{\mathrm{R}} \\
(\mathrm{min})\end{array}$ & $\begin{array}{c}\text { precursor } \\
{[\mathrm{M}+3 \mathrm{H}]^{3+}}\end{array}$ & $\mathrm{b}_{4}$ & $b_{5}$ & $b_{6}$ & $y_{3}$ & $\mathrm{y}_{4}$ & $\mathrm{y}_{5}$ & $\mathrm{y}_{6}$ & $\begin{array}{l}\text { other diagnostic product ions } \\
\text { (non-oxidized) }\end{array}$ \\
\hline IR0 & - & 5.98 & 541.6 & $\mathrm{X}$ & $\mathrm{X}$ & $\mathrm{X}$ & $\mathrm{X}$ & $\mathrm{X}$ & $\mathrm{X}$ & $\mathrm{X}$ & \\
\hline $\mathrm{M}+\mathrm{O}$ & Y9 & 1.90 & 546.9 & $\mathrm{X}$ & $\mathrm{X}$ & $\mathrm{X}$ & $\mathrm{X}$ & $\mathrm{O}$ & $\mathrm{O}$ & $\mathrm{O}$ & \\
\hline $\mathrm{M}+\mathrm{O}$ & Y10 & 2.42 & 546.9 & $\mathrm{X}$ & $\mathrm{X}$ & $\mathrm{X}$ & $\mathrm{O}$ & $\mathrm{O}$ & $\mathrm{O}$ & $\mathrm{O}$ & \\
\hline $\mathrm{M}+\mathrm{O}$ & Y5 & 4.31 & 546.9 & $\mathrm{X}$ & $\mathrm{O}$ & $\mathrm{O}$ & $\mathrm{X}$ & $\mathrm{X}$ & $\mathrm{X}$ & $\mathrm{X}$ & \\
\hline $\mathrm{M}+\mathrm{O}$ & $\mathrm{Y} 9, \mathrm{Y} 10^{b}$ & 4.57 & 546.9 & $\mathrm{X}$ & $\mathrm{X}$ & $\mathrm{X}$ & $\mathrm{X} / \mathrm{O}$ & $\mathrm{O}$ & $\mathrm{O}$ & $\mathrm{O}$ & \\
\hline IR1A & - & 5.43 & 568.3 & $\mathrm{X}$ & $\mathrm{X}$ & $\mathrm{X}$ & $\mathrm{X}$ & $\mathrm{X}$ & $\mathrm{X}$ & $\mathrm{X}$ & \\
\hline $\mathrm{M}+\mathrm{O}$ & Y9 & 2.09 & 573.6 & $\mathrm{X}$ & $\mathrm{X}$ & $\mathrm{X}$ & $\mathrm{X}$ & $\mathrm{O}$ & $\mathrm{O}$ & $\mathrm{O}$ & \\
\hline $\mathrm{M}+\mathrm{O}$ & $\mathrm{Y} 9, \mathrm{Y} 10^{b}$ & 2.29 & 573.6 & $\mathrm{X}$ & $\mathrm{X}$ & $\mathrm{X}$ & $\mathrm{X} / \mathrm{O}$ & $\mathrm{O}$ & $\mathrm{O}$ & $\mathrm{O}$ & \\
\hline $\mathrm{M}+\mathrm{O}$ & $\mathrm{Y} 9, \mathrm{Y} 10^{b}$ & 2.57 & 573.6 & $\mathrm{X}$ & $\mathrm{X}$ & $\mathrm{X}$ & $\mathrm{X} / \mathrm{O}$ & $\mathrm{O}$ & & $\mathrm{O}$ & \\
\hline $\mathrm{M}+\mathrm{O}$ & $\mathrm{Y} 9, \mathrm{Y} 10^{b}$ & 4.00 & 573.6 & $\mathrm{X}$ & $\mathrm{X}$ & $\mathrm{X}$ & $\mathrm{X} / \mathrm{O}$ & $\mathrm{O}$ & $\mathrm{O}$ & $\mathrm{O}$ & \\
\hline $\mathrm{M}+\mathrm{O}$ & pY5 & 7.00 & 573.6 & $\mathrm{X}$ & $\mathrm{O}$ & $\mathrm{O}$ & $\mathrm{X}$ & $\mathrm{X}$ & $\mathrm{X}$ & $\mathrm{X}$ & \\
\hline $\mathrm{M}+2 \mathrm{O}$ & Y9 & 2.62 & 578.9 & $\mathrm{X}$ & $\mathrm{X}$ & $\mathrm{X}$ & $\mathrm{X}$ & 20 & $2 \mathrm{O}$ & $2 \mathrm{O}$ & \\
\hline $\mathrm{M}+2 \mathrm{O}$ & I4 & 2.94 & 578.9 & 20 & $2 \mathrm{O}$ & 20 & $\mathrm{X}$ & $\mathrm{X}$ & $\mathrm{X}$ & $\mathrm{X}$ & $b_{3}$ \\
\hline $\mathrm{M}+2 \mathrm{O}$ & Y10 & 3.13 & 578.9 & $\mathrm{X}$ & $\mathrm{X}$ & & 20 & $2 \mathrm{O}$ & $2 \mathrm{O}$ & & $\mathrm{x}_{2}$ \\
\hline $\mathrm{M}+2 \mathrm{O}$ & $\mathrm{Y9}{ }^{c}$ & 3.30 & 578.9 & $\mathrm{X}$ & $\mathrm{X}$ & $\mathrm{X}$ & & & & & $\mathrm{b}_{8}, \mathrm{z}_{3}$ \\
\hline $\mathrm{M}+2 \mathrm{O}$ & I4 & 3.67 & 578.9 & 20 & & & $\mathrm{X}$ & $\mathrm{X}$ & $\mathrm{X}$ & $\mathrm{X}$ & $b_{3}$ \\
\hline IR1B & - & 9.64 & 568.3 & $\mathrm{X}$ & $\mathrm{X}$ & $\mathrm{X}$ & $\mathrm{X}$ & $\mathrm{X}$ & $\mathrm{X}$ & $\mathrm{X}$ & \\
\hline $\mathrm{M}+\mathrm{O}$ & Y5 & 7.42 & 573.6 & $\mathrm{X}$ & $\mathrm{O}$ & $\mathrm{O}$ & $\mathrm{X}$ & $\mathrm{X}$ & $\mathrm{X}$ & $\mathrm{X}$ & \\
\hline $\mathrm{M}+\mathrm{O}$ & Y10 & 7.57 & 573.6 & $\mathrm{X}$ & $\mathrm{X}$ & $\mathrm{X}$ & $\mathrm{O}$ & & $\mathrm{O}$ & $\mathrm{O}$ & \\
\hline IR1C & - & 5.20 & 568.3 & $\mathrm{X}$ & $\mathrm{X}$ & $\mathrm{X}$ & $\mathrm{X}$ & $\mathrm{X}$ & $\mathrm{X}$ & $\mathrm{X}$ & \\
\hline $\mathrm{M}+\mathrm{O}$ & Y9 & 1.94 & 573.6 & $\mathrm{X}$ & $\mathrm{X}$ & $\mathrm{X}$ & $\mathrm{X}$ & $\mathrm{O}$ & $\mathrm{O}$ & $\mathrm{O}$ & \\
\hline $\mathrm{M}+\mathrm{O}$ & Y9 & 2.14 & 573.6 & $\mathrm{X}$ & $\mathrm{X}$ & $\mathrm{X}$ & $\mathrm{X}$ & $\mathrm{O}$ & $\mathrm{O}$ & $\mathrm{O}$ & \\
\hline $\mathrm{M}+\mathrm{O}$ & Y5 & 3.61 & 573.6 & $\mathrm{X}$ & $\mathrm{O}$ & $\mathrm{O}$ & $\mathrm{X}$ & $\mathrm{X}$ & $\mathrm{X}$ & $\mathrm{X}$ & \\
\hline $\mathrm{M}+\mathrm{O}$ & Y9 & 3.80 & 573.6 & $\mathrm{X}$ & $\mathrm{X}$ & $\mathrm{X}$ & $\mathrm{X}$ & $\mathrm{O}$ & $\mathrm{O}$ & $\mathrm{O}$ & \\
\hline $\mathrm{M}+\mathrm{O}$ & pY10 & 8.29 & 573.6 & $\mathrm{X}$ & $\mathrm{X}$ & $\mathrm{X}$ & $\mathrm{O}$ & $\mathrm{O}$ & $\mathrm{O}$ & $\mathrm{O}$ & \\
\hline
\end{tabular}

${ }^{a}$ Non-oxidized product ions are marked with $\mathrm{X}$, singly oxidized product ions $(\mathrm{X}+\mathrm{O})$ with $\mathrm{O}$, and doubly oxidized $(\mathrm{X}+2 \mathrm{O})$ with $2 \mathrm{O}$. Accurate masses of the precursors and product ions are provided in Table S6. ${ }^{b}$ Two oxidation products that could not be resolved chromatographically. ${ }^{c}$ No oxidized product ions were observed, but the non-oxidized product ions rule out there being other oxidation sites.

graph quadrupole-time-of-flight mass spectrometer (UHPLC-QTOF-MS) (more details in Tables S2-S5, Figure S1).

First, the UV exposure time of the $\mathrm{TiO}_{2}$ photocatalyic oxidation reactions of the studied phosphopetides was optimized. The peptides decomposed under $\mathrm{TiO}_{2}$ photocatalysis within $15 \mathrm{~min}$ (Figure S2a). The initial, but not always the most abundant, oxidation products were $\mathrm{M}+\mathrm{O}$ and $\mathrm{M}+2 \mathrm{O}$ products. All initial oxidation products of each peptide followed similar kinetics. The UV exposure times for structural elucidation of the $\mathrm{M}+\mathrm{O}$ and $\mathrm{M}+2 \mathrm{O}$ products were chosen based on their abundances (Figure S2b) and were $2 \mathrm{~min}$ for IR1A and IR1C, 4 min for IR0, and $6 \mathrm{~min}$ for IR1B. A kinetic study was not performed for IR3, as oxidation products were not observed either with UV exposure time of 1 or $6 \mathrm{~min}$.

The mass spectra of the peptides IR0, IR1A, IR1B, IR1C, and IR3, analyzed by the developed UHPLC-ESI-MS method, showed multiple protonated molecules (one to four protons), with the $[\mathrm{M}+3 \mathrm{H}]^{+3}$ ion being the most abundant. The number of protons, i.e., the charge-state distribution, was strongly affected by both the phosphorylation and the oxidation states of the peptides. Owing to the addition of an acidic phosphate group, the relative abundance of $[\mathrm{M}+4 \mathrm{H}]^{+4}$ ion of the phosphorylated peptides (IR1A, IR1B, IR1C, and IR3) was significantly lower $(1-2 \%)$ than that of the nonphosphorylated peptide IR0 (35\%). On the other hand, oxidation of IR0, IR1A, IR1B, and IR1C clearly increased the charge state so that the relative abundance of $[\mathrm{M}+2 \mathrm{H}]^{+2}$ ion clearly decreased compared to that of $[\mathrm{M}+3 \mathrm{H}]^{+3}$. The changes in the charge states are most likely due to conformational changes of the peptides with respect to oxidation and phosphorylation reactions. The triple protonated molecule was the most abundant ion for nearly all the peptides and their $\mathrm{M}+\mathrm{O}$ and $\mathrm{M}+2 \mathrm{O}$ oxidation products, thus it was selected as the precursor ion for product ion analyses.

The most common product ions of the peptides were sequence diagnostic single protonated $\mathrm{N}$-terminal $\mathrm{b}$-ions and C-terminal $y$-ions. The oxidation sites of the $\mathrm{M}+\mathrm{O}$ and $\mathrm{M}+2 \mathrm{O}$ products of the studied peptides were determined based on the oxidized and the non-oxidized $b$ - and $y$-ions of the peptides obtained (Table 1). As an example, five $\mathrm{M}+\mathrm{O}$ oxidation products of the nonphosphorylated peptide IR0 were observed in the ion chromatogram of $[(\mathrm{IRO}+\mathrm{O})+3 \mathrm{H}]^{+3}$ at $\mathrm{m} / z 546.9$ (Figure S1). The product ion spectrum of the $\mathrm{M}+\mathrm{O}$ product of IR0 eluted at $1.90 \mathrm{~min}$, showed an oxidized $\mathrm{y}_{4}$-ion and a nonoxidized $\mathrm{y}_{3}$-ion, which indicated that the oxidation site was tyrosine 9 (Y9). The $\mathrm{M}+\mathrm{O}$ product at $2.42 \mathrm{~min}$ was oxidized at Y10, as an oxidized $y_{3}$-ion was observed. Since $y_{1^{-}}$and $y_{2}$-ions were not observed, the assignment of the oxidation site to Y10 was not explicit as arginine 11 (R11) or lysine 12 (K12) may also be oxidized. However, the reaction rate of hydroxyl radicals with $\mathrm{Y}\left(1.3 \times 10^{10} \mathrm{M}^{-1} \mathrm{~s}^{-1}\right)$ is approximately an order of magnitude higher than with $\mathrm{R}\left(3.5 \times 10^{9} \mathrm{M}^{-1} \mathrm{~s}^{-1}\right)$ and two orders of magnitude higher than with $\mathrm{K}\left(3.5 \times 10^{8} \mathrm{M}^{-1} \mathrm{~s}^{-1}\right)$. ${ }^{6}$ Thus, we assume that $\mathrm{Y} 10$ is more readily oxidized than R11 or K12. Similar data interpretation also applies to the other identifications. In summary, all tyrosine residues of IR0 were oxidized, and oxidation at other amino acids was not observed. This is in agreement with the reaction rate constant of tyrosine with hydroxyl radicals, which is at least an order of magnitude higher 
than that of the other amino acids present in the studied peptides. $^{6}$

Similar to that described above, the sites of oxidation were determined for the monophosphorylated peptides IR1A, IR1B, and IR1C (Table 1). $\mathrm{TiO}_{2}$ photocatalysis produced eight $\mathrm{M}+\mathrm{O}$ and five $\mathrm{M}+2 \mathrm{O}$ products of IR1A, two $\mathrm{M}+\mathrm{O}$ products of IR1B, and five $\mathrm{M}+\mathrm{O}$ products of IR1C. By considering all oxidation products, the oxidation site was at a nonphosphorylated tyrosine in 16 products, at a phosphorylated tyrosine in two products and at isoleucine 4 (I4) in two products. These results clearly support the conclusion that the preferred oxidation site is at the tyrosine residue. The two observed $\mathrm{M}+2 \mathrm{O}$ products of isoleucine (based on diagnostic $b_{4}+2 \mathrm{O}$ ion) are consistent with the reaction rate constant of hydroxyl radicals with isoleucine $\left(1.8 \times 10^{9} \mathrm{M}^{-1} \mathrm{~s}^{-1}\right)$ being the third highest after tyrosine and arginine and approximately an order of magnitude higher than those of the other amino acids $\left(7.5 \times 10^{7}-5.1 \times 10^{8} \mathrm{M}^{-1} \mathrm{~s}^{-1}\right)$ present in the studied IR peptides. ${ }^{6}$ The results also clearly show that the monophosphorylated peptides IR1A, IR1B, and IR1C were preferentially oxidized at nonphosphorylated tyrosines. An exception to this was that both IR1A and IR1C produced a minor $\mathrm{M}+\mathrm{O}$ product, in which the oxidation site was the phosphorylated tyrosine. These results were strongly supported by the finding that no oxidation products of the triply phosphorylated peptide IR3 (all tyrosines phosphorylated: pY5, pY9, and pY10) were observed. Thus, the results suggest that phosphorylation of tyrosine significantly inhibits its oxidation under $\mathrm{TiO}_{2}$ photocatalysis conditions.

In addition to $\mathrm{M}+\mathrm{O}$ oxidation products, five $\mathrm{M}+2 \mathrm{O}$ products were observed for IR1A (Table 1 ). Traces of $\mathrm{M}+2 \mathrm{O}$ products of IR0, IR1B, and IR1C were also observed, but at quantities lower than those needed for reliable identification based on acquisition of the product ion spectra. Interestingly, both oxygens in the $\mathrm{M}+$ $2 \mathrm{O}$ oxidation products attacked the same amino acid (Table 1 ). For instance, the product ion spectrum of the $\mathrm{M}+2 \mathrm{O}$ product of IR1A at 2.62 min showed a double oxidized $\mathrm{y}_{4}$-ion and a nonoxidized $\mathrm{y}_{3}$-ion, which indicates double oxidization of Y9. The oxidation sites of other $\mathrm{M}+2 \mathrm{O}$ products were similarly assigned.

Although the most favored oxidization site was shown to be at a nonphosphorylated tyrosine, two minor $\mathrm{M}+\mathrm{O}$ products of IR1A and IR1C were also identified with oxidation at a phosphorylated tyrosine. Interestingly, these two products eluted later in the reversed-phase C18 liquid chromatography conditions than did the respective non-oxidized peptide. Instead, the $\mathrm{M}+\mathrm{O}$ and $\mathrm{M}+2 \mathrm{O}$ products in which the oxidation occurred at a nonphosphorylated tyrosine eluted earlier than the respective non-oxidized peptides. Thus, oxidation of the phosphorylated tyrosine rendered the peptide more hydrophobic increasing its retention within the C18 column, whereas oxidation at a nonphosphorylated tyrosine yields more polar products, which decreases its retention compared with the respective non-oxidized peptide. Hydroxylation of a phosphorylated tyrosine may enable internal hydrogen bonding between the formed hydroxyl group and the phosphate group thus rendering the peptide more hydrophobic.

The possible reactive oxygen species involved in $\mathrm{TiO}_{2}$ photocatalysis include hole $\left(\mathrm{h}^{+}\right)$on the $\mathrm{TiO}_{2}$ surface, the hydroxyl radical $\left({ }^{\bullet} \mathrm{OH}\right)$, the superoxide ion $\left(\mathrm{O}_{2}{ }^{\bullet-}\right)$, and the singlet oxygen $\left({ }^{1} \mathrm{O}_{2}\right) \cdot{ }^{9}$ In addition, $\mathrm{H}_{2} \mathrm{O}_{2}$ and $\mathrm{O}_{2}$ are involved in the photocatalytic oxidation reactions. The reaction rate of hydroxyl radical with tyrosine $\left(1.3 \times 10^{10} \mathrm{M}^{-1} \mathrm{~s}^{-1}\right)^{6}$ is significantly higher than those of either the superoxide ion or the singlet oxygen $\left(1.0 \pm 0.2 \times 10^{1}\right.$ and $0.8-0.9 \times 10^{7} \mathrm{M}^{-1} \mathrm{~s}^{-1}$, respectively). ${ }^{17}$ Moreover, the oxidation of tyrosine residue is more likely to be mediated by hydroxyl radicals than by surface holes, since basic reaction conditions $(\mathrm{pH}=10.5)$ were chosen to prevent the adsorption of the peptides onto the $\mathrm{TiO}_{2}$ surface. At this $\mathrm{pH}$, the $\mathrm{TiO}_{2}$ surface is negatively charged, ${ }^{18}$ and electrostatic repulsion orients the negatively charged phenolic moiety of the tyrosine residue and the negatively charged phosphate group at the phosphorylated tyrosine out from the $\mathrm{TiO}_{2}$ surface, which results in decreased interaction and oxidation of tyrosine residues of the peptides with the holes. It has also been suggested that organic molecules should be adsorbed onto the $\mathrm{TiO}_{2}$ surface ${ }^{19}$ to react with the short-lived singlet oxygen (lifetime $2-3 \mu \mathrm{s}){ }^{20}$ Hence, hydroxyl radicals obviously play the major role in initiating oxidation reactions of the tyrosine residue of the studied peptides.

$\mathrm{Xu}$ and Chance presented a scheme of a hydroxyl radicalinitiated oxidation mechanism of tyrosine residue ${ }^{6}$ in which the hydroxyl radical reacts rapidly with the tyrosine residue that produces the dihydroxycyclohexadienyl radical. The most obvious reaction site is the meta-position, due to the directing effect of the original hydroxyl substituent at the para-position. The dihydroxycyclohexadienyl radical then reacts with oxygen (via addition) followed by the elimination of the hydroperoxyl radical to form $\alpha$-hydroxycyclohexadienone, which is finally converted to 3,4-dihydroxyphenylalanine residue (DOPA) $(\mathrm{M}+$ O product). Further hydroxylation of DOPA via the same oxidation mechanism can produce trihydroxyphenylalanine residue $(\mathrm{M}+2 \mathrm{O}$ product $)$. The inhibitory effect of phosphorylation upon the oxidation of tyrosine may be explained by the presented oxidation mechanism. The phosphorylation of the hydroxyl group of tyrosine (para-position) prevents the formation of the $\alpha$-hydroxycyclohexadienone intermediate and thus inhibits oxidation of phosphorylated tyrosine. Even if the two meta-positions of each tyrosine are the most favored oxidation sites, our results suggest that oxidation may also occur at other positions, since it was observed that four different $\mathrm{M}+\mathrm{O}$ products of IR1A were oxidized at $Y 9$, three different $\mathrm{M}+\mathrm{O}$ products of IR1A were oxidized at Y10, and three different $\mathrm{M}+\mathrm{O}$ products of IR1C were oxidized at Y9. However, the exact oxidation site at tyrosine was not elucidated in this study.

In conclusion, we have shown that $\mathrm{TiO}_{2}$ photocatalysis provides a valuable method to study oxidation reactions of biomolecules, as it produces the same reactive oxygen species (hydroxyl radicals, superoxide ions, and singlet oxygen) as biological systems. In this study, $\mathrm{TiO}_{2}$ photocatalysis was for the first time used for studying oxidation reactions of phosphorylated peptides. The hydroxyl radical initiated oxidation reactions resulted mainly in hydroxylation of nonphosphorylated tyrosine whereas phosphorylation was in most cases shown to effectively protect the tyrosine residue from oxidation.

\section{ASSOCIATED CONTENT}

S Supporting Information

The Supporting Information is available free of charge on the ACS Publications website at DOI: 10.1021/jacs.6b02472.

Experimental details and data (PDF)

\section{AUTHOR INFORMATION}

\section{Corresponding Author}

*risto.kostiainen@helsinki.fi

\section{Notes}

The authors declare no competing financial interest. 


\section{ACKNOWLEDGMENTS}

The research leading to these results received funding from the European Research Council under the European Union's Seventh Framework Program (FP/2007-2013)/ERC grant agreement no. 311705 .

\section{REFERENCES}

(1) Hunter, T. Cell 2000, 100, 113.

(2) Hunter, T. Curr. Opin. Cell Biol. 2009, 21, 140.

(3) Julien, S. G.; Dube, N.; Hardy, S.; Tremblay, M. L. Nat. Rev. Cancer 2011, 11, 35.

(4) Krause, D. S.; Van Etten, R. A. N. Engl. J. Med. 2005, 353, 172.

(5) Butterfield, D. A.; Perluigi, M.; Reed, T.; Muharib, T.; Hughes, C. P.; Robinson, R. A. S.; Sultana, R. Antioxid. Redox Signaling 2012, 17, 1610.

(6) Xu, G.; Chance, M. R. Chem. Rev. 2007, 107, 3514.

(7) Davies, M. I. Biochim. Biophvs. Acta, Proteins Proteomics 2005, 1703, 93.

(8) Permentier, H. P.; Jurva, U.; Barroso, B.; Bruins, A. P. Rapid Commun. Mass Spectrom. 2003, 17, 1585.

(9) Fujishima, A.; Zhang, X.; Tryk, D. A. Surf. Sci. Rep. 2008, 63, 515.

(10) Calza, P.; Pazzi, M.; Medana, C.; Baiocchi, C.; Pelizzetti, E. I. Pharm. Biomed. Anal. 2004, 35, 9.

(11) Nissilä, T.; Sainiemi, L.; Karikko, M.; Kemell, M.; Ritala, M.; Franssila, S.; Kostiainen, R.; Ketola, R. A. Lab Chip 2011, 11, 1470.

(12) Ruokolainen, M.; Valkonen, M.; Sikanen, T.; Kotiaho, T.; Kostiainen, R. Eur. I. Pharm. Sci. 2014, 65, 45.

(13) Ruokolainen, M.; Gul, T.; Permentier, H.; Sikanen, T.; Kostiainen, R.; Kotiaho, T. Eur. I. Pharm. Sci. 2016, 83, 36.

(14) Jones, B. J.; Vergne, M. J.; Bunk, D. M.; Locascio, L. E.; Hayes, M. A. Anal. Chem. 2007, 79, 1327.

(15) Antoniou, M. G.; Shoemaker, J. A.; De la Cruz, A. A.; Dionysiou, D. D. Environ. Sci. Technol. 2008, 42, 8877.

(16) Liu, I.; Lawton, L. A.; Robertson, P. K. Environ. Sci. Technol. 2003, 37, 3214.

(17) Sharma, V. K.; Rokita, S. E. Wilev Series of Reactive Intermediates in Chemistry and Biology: Oxidation of Amino Acids, Peptides, and Proteins: Kinetics and Mechanism; ${ }_{i}$ John Wiley \& Sons: Somerset, NJ, 2012; pp 122-204.

(18) Pelton, R.; Geng, X.; Brook, M. Adv. Colloid Interface Sci. 2006, 127, 43.

(19) Daimon, T.; Hirakawa, T.; Nosaka, Y. Electrochemistry 2008, 76, 136.

(20) Daimon, T.; Nosaka, Y. I. Phvs. Chem. C 2007, 111, 4420. 